\author{
竹内嘉 隆*1, 宮田昌 悟*2
}

\title{
Micro Cell Patterning Technology by Dielectrophoresis and Application to Regenerated Cartilage
}

\author{
Yoshitaka TAKEUCHI and Shogo MIYATA*3 \\ ${ }^{* 3}$ Graduate School of Science and Technology, Keio University, \\ 3-14-1 Hiyoshi, Kouhoku-ku, Yokohama-shi, Kanagawa, 223-8522 Japan
}

\begin{abstract}
Recently, microfabrication tools have been utilized to quantify the role of the cellular microenvironment on cell activity and function. Improving tissue regeneration by cell culture on scaffold material will also require tools to control cellular organization in 3-dimentional (3-D) condition. Our objective was to improve cartilage tissue engineering using 3-D cell organization technology. In this study, we developed an anisotropic cartilaginous tissue by cell patterning within hydrogel slabs using dielectrophoretic (DEP) forces. Our data indicate that the embedded chondrocytes remained viable and reconstructed cartilaginous tissue along the patterned cell array. In conclusion, DEP cell patterning may become a useful approach for reconstructing anisotropic structure in cartilage regeneration.
\end{abstract}

Key Words: Biomaterial, Biomechanics, Anisotropy, Dielectrophoresis, Regenerated Cartilage, Tissue Engineering

\section{1. 緒}

近年, 損傷した生体組織から細胞を取り出し, 生体 内あるいは生体外で培養し，再生された組織を体内に 㷌納させるという考えを根幹に持つ再生医療工学に注 目が集まっている。細胞は生体外で二次元的に培養す るだけでは機能を失う(脱分化する)可能性が高いこと から，三次元的に培養する必要がある．細胞を三次元 培養する際には足場となる担体を必要とし，コラーゲ ンゲル，アガロースゲルに代表されるような天然高分 子材料(1) (4)，ポリ乳酸，ポリグリコール酸などの合成 高分子(5) を用いた多孔質構造の培養基材に関する研 究が報告されている。しかしながら，現在までのとこ ろ，細胞を三次元培養するだけでは組織再生には充分 とは言えず，より生体に近い組織を再生するためには 対象とする生体組織に特有の高次機能を発現させる必 要がある。

生体組織の機能は, 組織中の細胞-細胞間, 細胞-細

* 原稿受付 2010 年 1 月 27 日

${ }^{* 1}$ 慶應義熟大学大学院総合デザイン工学専攻 (苾 223-8522 横 浜方港北区日吉 3-14-1).

*2 正員, 慶隹義熟大学理工学部機械工学科.

E-mail : miyata@mech.keio.ac.jp
胞外基質間の相互作用に由来していることが多く， 骨・軟骨，血管，神経組織などは細胞の配列が組織の 機能と密接に関係している. 本研焭では生体内での修 復能に乏しいことから, 近年, 生体外での組織再生に 関する研究が広く進められている関節軟骨に注目し た.

関節軟骨は関節表面を覆う結合組織であり, 衝撃の 緩衝や低摩擦・低摩耗の潤滑能を持つ. 関節軟骨組織 の大部分は軟骨細胞が産生したコラーダンとプロテオ グリカンからなる軟骨基䫓と70〜80\%の水分から構 成されている。また，軟骨の組織は関節の摺動面に対 して深さ方向に不均一な構造を持ち，一般に摺動面か ら軟骨下骨に向かって表層, 中層, 下層と区分されて いる．軟骨組織中のコラーゲン線維は各層ごとに構造 が変化しており, 表層では摺動面に平行, 中層ではラ ンダムな網目構造, 下層では垂直方向に配向されてお り, 組織に加わる生理的な変形に応じて複雑な異方性 の材料特性を持つ組織である(6).

このような異方性組織の再生は，ゲルや多孔質体な どの培養担体に均一に細胞を分散する既存の手法では 困難であり，細胞の配列が制御された形で細胞の播種 が行われることが重要である。このような背景から細 胞配置のコントロールができる微粒子の集積化技術や 
マニピュレーション技術に注目が集まっている．集積 化技術には様々な手法があり，電圧勾配の傾きを利用 する誘電泳動(Dielectrophoresis: DEP) ${ }^{(7)} や$ Ink Jet Printing 法 ${ }^{(8)}$ などがある. 特に, 近年では細胞の集積 化やマニピュレーションに誘電泳動を用いた研究が広 く進められている。これは誘電泳動が細胞に直接触れ ることなく，迅速に集積化が行えるからである. 細胞 を対象とした研究には単一細胞のパターニングやマニ ピュレーションに関する研究(9) (13), 2 種類の細胞を交 互に線状に集積化する研究(14)，クラス夕状に細胞を集 積化し, 細胞機能の活性を評価する研究(15)(16) などの 報告がある。

しかしながら，誘電泳動を用いた細胞の集積化技術 を軟骨の再生に応用し，組織に異方性を実現する研究 は現在まで行われていない。また，誘電泳動が組織再 生に与える影響も十分に検討されているとは言えな い。そこで本研究では，誘電泳動を用いたハイドロゲ ル基材中での細胞集積化技術を確立し，その集積化技 術を用いてハイドロゲル内で軟骨細胞の集積化を行 い, 培養担体内で細胞配列に異方性を有する再生軟骨 組織を作製した。また，誘電泳動による細胞集積化が 細胞外基質の産生に及ぼす影響について検討したので 報告する。

\section{2. 試料及び実験方法}

$2 \cdot 1$ 誘電泳動用チャンバの作製と泳動原理 誘 電泳動実験用チャンバは導電性を有するITO(Indium Tin Oxide)膜付きスライドガラス $(25 \times 75 \times 1.1$ $\left.\mathrm{mm}^{3}\right) 2$ 枚とシリコンガスケット(厚み: $\left.500 \mu \mathrm{m}\right) 1$ 枚 を組み合わせて構築した，ITO膜の膜厚は 1200 $1600 \AA$ である。下部のITO膜付きスライドガラスの ITO膜上に厚膜フォトレジスト剤である SU-8(SU8, 10, MicroChem Corp., USA) 塗布し, 不均一な 電場を生む, スリット形状に ITO膜が露出する電極 構造を作製した [図 1 ( a ) ].スリット形状の電極は スライドガラス上の $10 \mathrm{~mm} \times 10 \mathrm{~mm}$ の領域に構築し， 露出されるスリット形状のITO膜電極は幅 $20 \mu \mathrm{m}$, 長さ $15 \mathrm{~mm}$, 電極間距離は $100 \mu \mathrm{m}$ とした。これによ り上部スライドガラスのITO膜と下部スライドガラ スのスリット形状の電極間に交流電場を印加すること で不均一な電界強度分布が生じ, 細胞の誘電泳動が実 現される。本研究で注電界強度の極小部へ細胞が集積 される負の誘電泳動 (negative-dielectrophoresis : $\mathrm{n}^{-}$ DEP) 用いた。誘電泳動実験中の細胞の挙動を図 1 (b)に示す.

$2 \cdot 2$ 仔ウシ軟骨細胞の単離と三次元培養軟骨
細胞は仔ウシ関節軟骨由来の細胞を用いた，生後 2-3 カ月の仔ウシの肩関節部より軟骨組織片を採取し，コ ラゲナーゼ溶液内で擋汼することで酵素的に軟骨細胞 を単離した。単離された軟骨細胞は細胞密度 $2.0 \times$ $10^{7}$ cells $/ \mathrm{ml}$ になるように低導電性の細胞等張液に懸 濁した. その後, 同体積の $3.0 \%$ 低融点アガロース溶 液(A2576, Type IX-A, SIGMA, USA) と混合して 細胞密度 $1.0 \times 10^{7} \mathrm{cells} / \mathrm{ml}$ の軟骨細胞を含む $1.5 \%$ のアガロース溶液として調製し, 誘電泳動用チャンバ へ注入した.チャンバに交流電場を印加することで誘 電泳動現象を生じ, 細胞を集積した. 交流電場の印加 後に泠却，ゲル化して培羪体とした。

誘電泳動ではファンクションジェネレータ, 電力増 幅器を用いて安定した交流電場をチャンバに印加し た.チャンバに印加される電圧はオシロスコープによ りモニタリングした。電圧は $10,20 \mathrm{~V}_{\mathrm{p}-\mathrm{p}}$, 周波数は $10 \mathrm{kHz}$ とした. 印加時間は $20 \mathrm{~min}$ とし, 誘電泳動後 にゲル化するための冷却時間は $4^{\circ} \mathrm{C}$ 下で $40 \mathrm{~min}$ とし た。

ゲル化した培湌試料は細胞培養ディッシュに移動 し, $37^{\circ} \mathrm{C}, 5 \% \mathrm{CO}_{2}$ 環境下で培養した。なお，コントロ ール試料群として同条件下で電場の印加を行わずに均

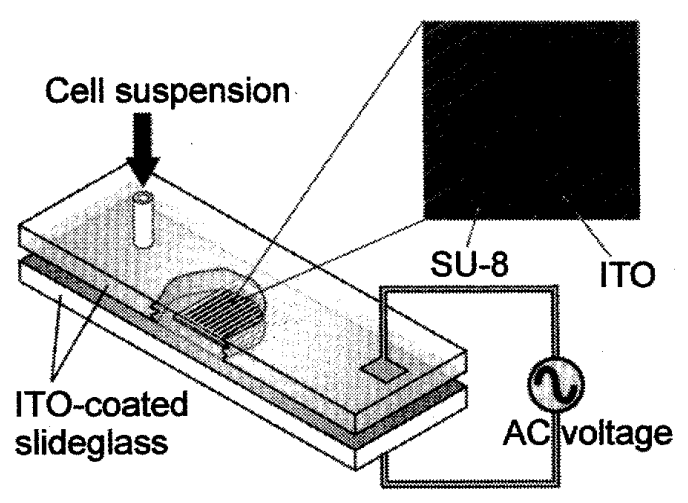

(a)

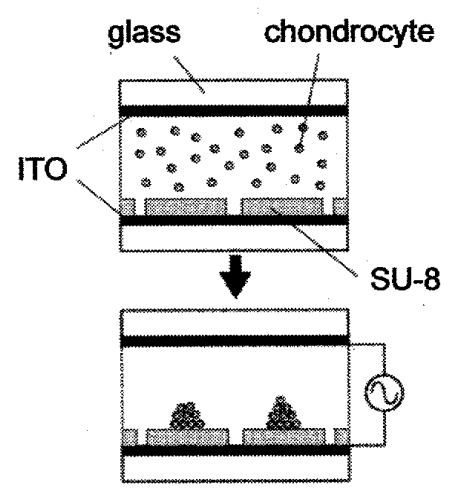

(b)

Fig. 1 (a) DEP chamber and (b) schematic of chondrocyte patterning in the chamber 
一に細胞を分散した試料 $\left(0 \mathrm{~V}_{\mathrm{p}-\mathrm{p}}\right)$ を作製して比較対象 とした。培養液には DMEM/F $-12+20 \% \mathrm{FBS}+50$ $\mu \mathrm{g} / \mathrm{ml} \mathrm{L}$-ascorbic acid を用いた。培養期間は 7 日間 とした.

なお，ゲル培養体は 1 組の仔ウシ肩関節から抽出さ れた軟骨細胞を用いて作製し，誘電泳動での印加電压 条件 $0,10,20 \mathrm{~V}_{\mathrm{p}-\mathrm{p}}$ に扔いて，それぞれ $n=3-4$ とな る試料群を構成して実験を行った。 また, 実験は 3 組

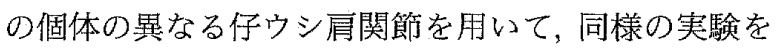
3 回行い再現性を確䜑した. 実験結果は, 仔ウシの個 体差による各回の間の測定值のばらつきが大きいこ と, また, 3 回の実験が定性的にはすべて同様の傾向 を示したことを考慮して，3回行った実験の結果から 代表例として 1 回分の結果を示した。

$2 \cdot 3$ 組織学的評価および生化学的評価 組織学 的評価として培亘 0,7 日において試料の細胞外基質 を染色するサフラニン $\mathrm{O}$ 染色を行い, 光学顕微鏡下で 観察した.

生化学評価は培養 7 日の試料を対象として, 軟骨の 細胞外基質の主要成分の一つである硫酸化グリコサミ ノグリカン (sGAG) と細胞数の定量を行った. $\mathrm{sGAG}$ 含有量の定量にはDMMB assay(17)を用いた。標準 腹には shark chondroitin'sulfate(C4384, SIGMA,
USA）を用いて，波長 $540 \mathrm{~nm}$ における吸光度測定を 行った. 組織内の細胞数測定にはHoechst fluorometric DNA assay ${ }^{(18)}$ を用いて, 総 DNA 含有量を 定量した。標準液には calf thymus DNA を用い, 蛍 光度測定は Ex $365 \mathrm{~nm} / \mathrm{Em} 468 \mathrm{~nm}$ の条件で行った。 細胞 1 個当たりのDNA 含有量を $7.7 \mathrm{pg}$ として上記 で定量した総 DNA 含有量から試料中の総細胞数を算 出した(21).

測定された 1 試料あたりの $\mathrm{sGAG}$ 含有量, 総細胞 数, 1 軟骨細胞あたりの sGAG 産生量は統計学的に有 意差を評価した，統計学的な比較には $\mathrm{t}$ 検定を用い て, 有意水準は $5 \%$ とした.

\section{3. 結果}

誘電泳動により軟骨細胞は八イドロゲル中の ITO スリット電極間に配列が制御された形で凝集塊が形成 された。また，組織学的評価としては，培養 0,7 日の 試料の染色像を比較すると, 培養によって染色範团の 増加が観察され, 細胞外基質の産生が確認された（図 2).また，集積化を行うことで細胞外基質の産生領域 を図 $2 \mathrm{a}-2$ に示す均一なものから図 $2 \mathrm{~b}-2$ のようなス リット形状に制御することができ, 組織再生領域に異 方性を示す培養軟骨を作製することができた。

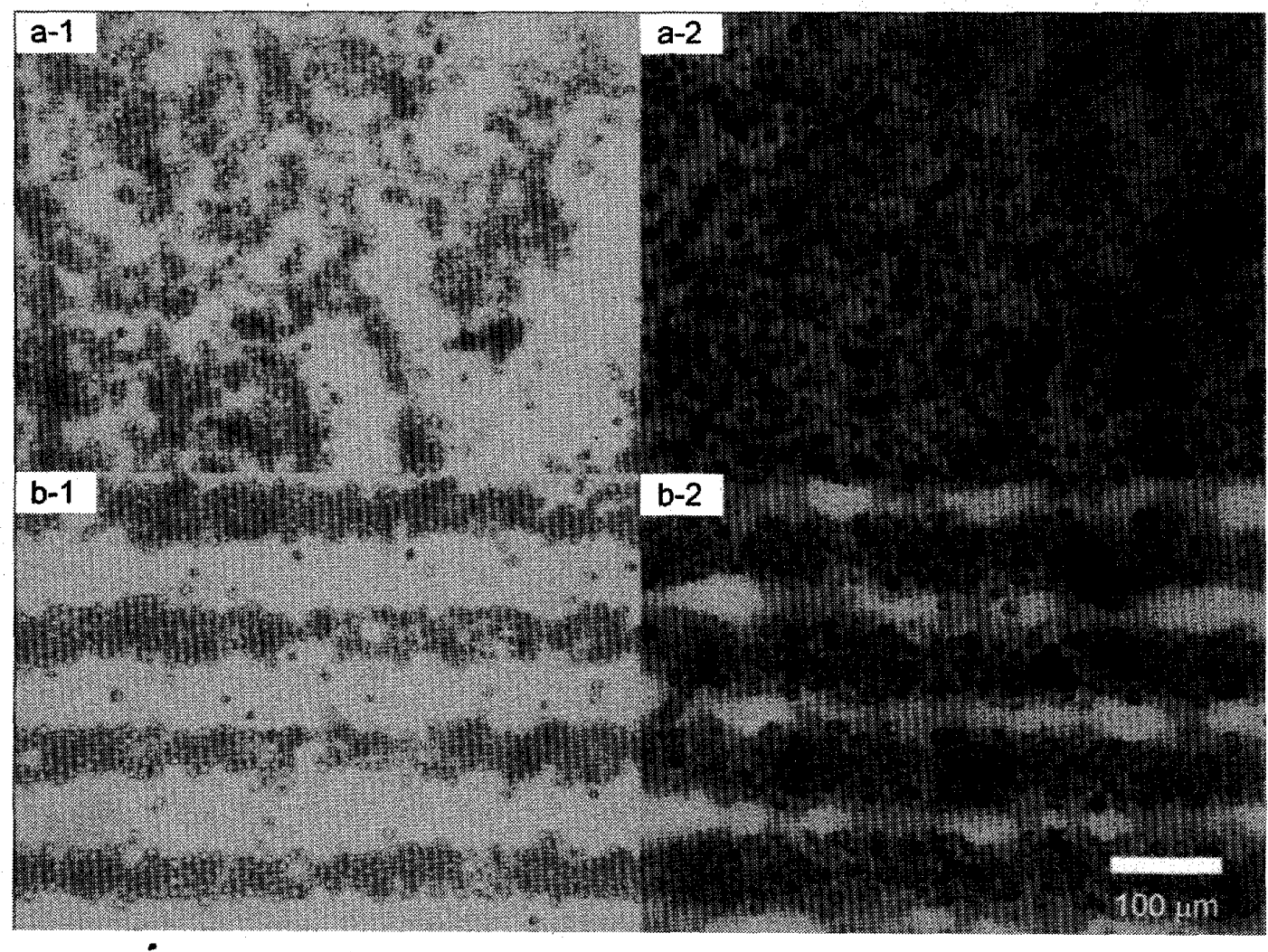

Fig. 2 (a) Chondrocyte-seeded agarose and (b) chondrocyte clusters in agarose gel cultured for 0 dey (left) and 7 deys (right) 
生化学的評価では，異なる個体由来の肩関節を用い て行った 3 回の実験のすべてにおいで，同様の傾向を 示す結果が得られた。しかしながら，仔ウシの個体差 に由来する各回の測定值の差が大きいため，ここでは

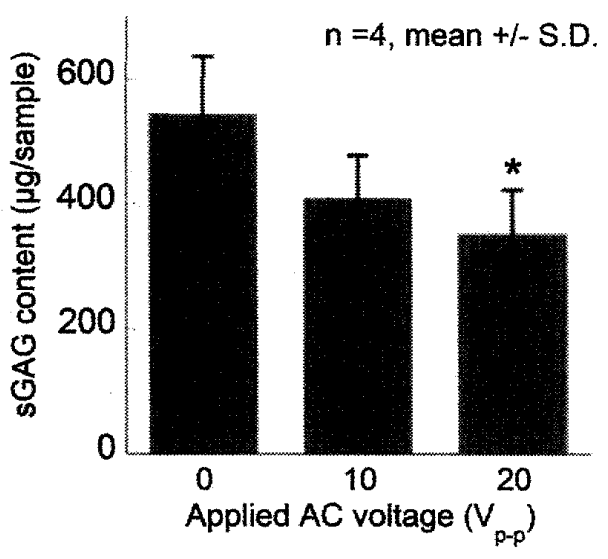

Fig. 3 Sulfated-GAG content of specimens cultured for 7 days. ${ }^{*}$ indicates a significant difference from 0 $\mathrm{V}$ groups $(p<0.05)$

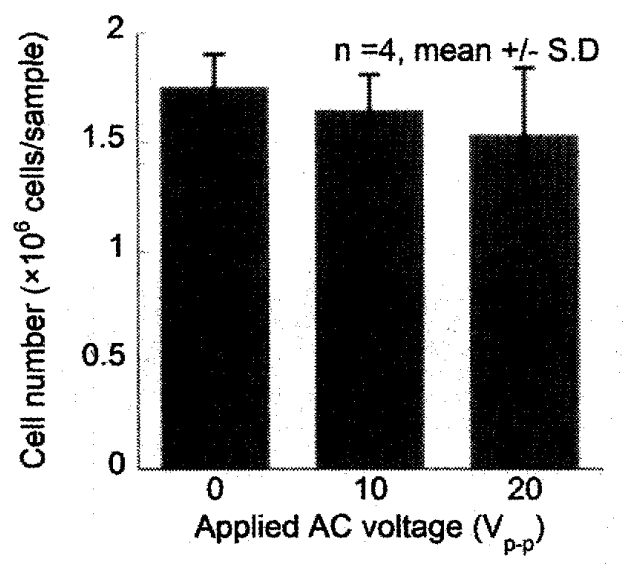

Fig. 4 Cell number in specimens cultured for 7 deys. Dashed line indicates the cell number of specimens at day 0

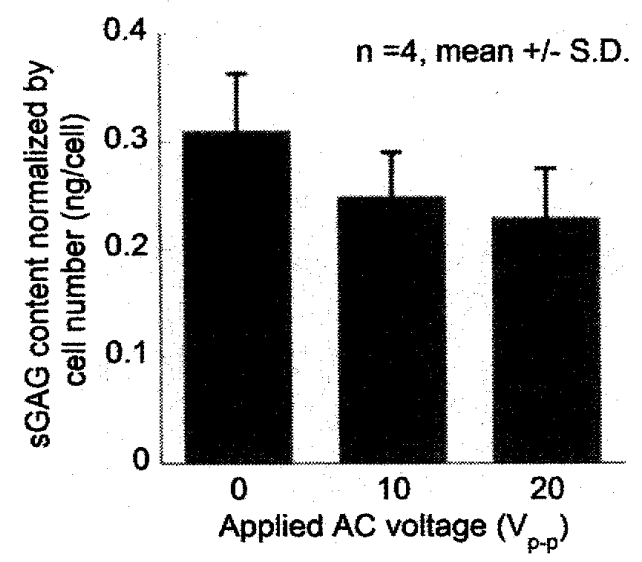

Fig. 5 Sulfated-GAG content synthesized by one cell in cultured specimens
代表例として 1 回分の実験結果を示す。7 日間培養さ れた試料内の総 $\mathrm{sGAG}$ 含有量では，細胞が均一に分散 された培養体と比較して, 細胞が集積化された培養体 では減少する傾向がみられた，印加電圧 $10 V_{\mathrm{p}-\mathrm{p}}$ と 20 $\mathrm{V}_{\mathrm{p}-\mathrm{p}}$ の試料を比較すると $20 \mathrm{~V}_{\mathrm{p}-\mathrm{p}}$ において減少傾向が 強まった(図3).一方で, 試料内の細胞数では，す心゙ ての試料において初期細胞数からの増殖が見られた。 また, 細胞が均一に分散された培養体と比較して, 細 胞の集積化を行った培養体では総細胞数が低くなる傾 向がみられた(図 4)。また，細胞 1 個当たりの $\mathrm{sGAG}$ 含有量では，図 3 と同様に集積化を行った培養体にお いて細胞が均一に分散された培庫体より減少する傾向 がみられた(図 5)。

\section{4. 考 察}

本研究で用いた軟骨細胞のアガロースゲル培養法は Benya らによって提案され，軟骨細胞の分化状態を維 持して軟骨基質の産生が促進されることが報告されて いる(19). 本研究においても，アガロースゲル内で軟骨 細胞を培養することで, サフラニン $\mathrm{O}$ による染色範囲 の増加が観察され，ゲル内に軟骨組織が再構築される ことが確認された.これは誘電泳動によって集積化さ れた後にも, 細胞が生存しており, かつ, 組織の再構 築が進んだこと，細胞外基質同士が組織の再構築に伴 って, 結合した結果であると考えられる，細胞が均一 に分散された試料, 細胞の集積化を行った試料共に, 培養 0 日の培養体に比べ, 培養 7 日の試料では細胞が 球形状を維持していることがわかる，このことからも 細胞が脱分化することなく，細胞の分化状態が維持さ れること, 細胞の生存性が確認された。

生化学特性では，印加電圧の增加に伴って試料中の 培養後の総細胞数が小さくなる傾向がみられた(図 4).すべての試料において初期細胞数からの増加が見 られたことから，交流電場の印加条件に関わらず細胞 の生存性は保たれて細胞増殖が生じたが, 集積化する ことで細胞 1 個当たりの増殖空間が隇少した結果, 細 胞が集積化した試料では培湌後に総細胞数が低い值を 示す傾向にあったと考えられる。

図 3 における試料中の総 $\mathrm{sGAG}$ 含有量, 図 5 におけ る細胞 1 個当たりの sGAG 産生量の結果より, 集積化 を行うことで $\mathrm{sGAG}$ 産生量が減少する傾向にあるこ とがわかった. Albrechtら(16) は誘電泳動を用いて PEG ゲル中に細胞をクラスタ状に集積化することで 細胞の活性が減少傾向にあることを報告しており，本 研究の結果とも一致する．上述の結果には二つの要因 が推測される。 
一点目には，軟滑の再構築領域の差異が推測される (図 2 中の a-2, b-2). 細胞の集積化による異方性組 織の再生では再構築される組織の領域を限定するため に, アガロースゲル内部に再生される軟骨組織の総体 積が小さくなり，それに伴って sGAG 含有量が低下し たと考えられる、組織染色画像において染色された画 像領域の評価を行ったところ, 図 $2 \mathrm{a}-2$ の染色範囲を 1 とした場合に図 $2 \mathrm{~b}-2$ の染色範囲は約 0.7 であっ た。二次元の画像を元にした面積比による検討ではあ るが, 図 3 に示した $20 \mathrm{~V}_{\mathrm{p}-\mathrm{p}}$ の試料の0 $\mathrm{V}_{\mathrm{p}-\mathrm{p}}$ の試料に 対する $\mathrm{sGAG}$ 産生量の低下率が約 0.7 であることか ら再構築された体積の低下率とほぼ等しいと考えられ る.すなわち, 組織中の $\mathrm{sGAG}$ 含有量の減少は, アガ ロースゲル内に再生される組織の体積減少によるもの であり, 再生組織そのものの SGAG 濃度が低下したこ とによるものではないと推測される。しかしながら， ハイドロゲル中の再生組織の総体積の検討には, 本研 究で用いた 2 次元の組織染色画像では不十分であり, 今後は培養体中の細胞の形状 ・サイズの計測や培養体 中の総タンパク含有量の測定を行い詳細な評価を行う 必要がある。

\section{二点目には，高電圧の印加による細胞活性の低下が} 考えられる。与えられる電圧が大きくなるに従って， sGAG 産生量が減少する傾向が見られることから，交 流電圧の印加によって細胞活性が低下した可能性が示 唆された。軟骨細胞は誘電泳動によって細胞膜で分極 構造を取ると推測される。誘電泳動を用いた細胞集積 化では, 分極構造による細胞へのダメージの有無, 細 胞機能への影響などを明らかにする必要があると考え られる。

本研究では, 誘電泳動を用いたハイドロゲル内部で の細胞配列の制御技術を確立した。また，スリット形 状の細胞凝集塊をハイドロゲル内部に作製し，培養す ることで再生領域に異方性のある再生軟骨組織を作製 することができた，今後は，印加電压や誘電泳動中の 細胞表面における分極構造の変化を計测, 評価するこ とで誘電泳動による集積化が細胞機能に与える影響を 検討する予定である。

\section{5. 結 論}

誘電泳動を用いたハイドロゲル内への軟骨細胞の集 積化技術を確立した。ささらに，その細胞集積化技術を 用いて，アガロースダル中で軟骨細胞をスリット形状 に集積化した後に培養することで, 再生領域に異方性 を持つ再生軟骨を作製することができた。

\section{文献}

(1) Wakitani, S., Kimura, T., Hirooka, A., Ochi, T., Yoneda, M., Yasui, N., Owaki, H. and One, K., Repair of Rabbit Articular Surfaces with Allograft Chondrocytes Embedded in Collagen Gel, Journal of Bone and Joint Surgery, Vol. 71, No. 1 (1989), pp. 74-80.

(2) Ochi, M., Uchio, Y., Tobita, M. and Kuriwaka, M., Current Concepts in Tissue Engineering Technique for Repair of Carti alge Defect, Artificial Organs, Vol. 25, No. 3 (2001), pp. 172-179.

(3) Buschmann, M. D., Gluzband, Y. A., Grodzinsky, A. J., Kimura, J. H. and Hunziker, E. B., Chondrocytes in Agarose Culture Synthesize a Mechanically Functional Extracellular Matrix, Journal of Orthopaedic Research, Vol. 10, No.6 (1992), pp. 745-758.

(4) Underhill, G. H., Chen, A. A., Albrecht, D. R. and Bhatia, S. N., Biomaterials, Vol.28, No.2 (2007), pp. 256-270.

(5) Sttinger, M., Reitzel, D., Dauner, M., Hierlemann, H., Hammer, C., Kastenbauer, E., Planck, H., Burmester, G. R. and Bujia, J., Resorbable polyesters in cartilage engineering: affinity and biocompatibility of polymer fiber structure to chondrocyte, Journal of Biomedical Material Research, Vol. 33, No. 2 (1996), pp. 57-63.

(6) Guilak, F., Butler, D. L., Goldstein, S. A. and Mooney, D. J., eds., Functional Tissue Engineering, (2003), pp. 227-229, Splinger-Verlag.

(7) Jones, T. B., Electromechanics of Particles, (1995), pp. 34-62, Cambridge University Press.

(8) Ringeisen, B. R., Othon, C. M., Barron, J. A., Young, D. and Spargo, B. J., Jet-based methods to ptint living cells, Biotechnology Jounal, Vol.1, No.9 (2006), pp. 930-948.

(9) Schnelle, T., Hagedorn, R., Fuhr, G., Fiedler, S. and Müller, T., Three-dimensional electric field traps for cells-calculation and experimental verification, Biochimica et Biophysica Acta, Vol. 1157, No. 2 (1993), pp. 127-140.

(10) Fuhr, G., Glasser, H., Müller, T. and Schnelle, T., Cell manipulation and cultivation under a.c. electro field influence in highly conductive culture media, Biochimica et Biophysica Acta, Vol. 1201, No. 3 (1994), pp. 353-360.

(11) Voldman, J., Gray, M. L., Toner, M. and Schmidt, M. A., A microfabrication-based dynamic array cytometer, Analytical Chemistry, Vol.74, No.16 (2002), pp. 3984-3990.

(12) Rosenthal, A. and Voldman, J., Dielectrophoretic traps for single-particle patterning, Biophysical Journal, Vol. 88, No. 3 (2005), pp. 2193-2205.

(13) Mittal, N., Rosenthal, A. and Voldman, J., Lab on a Chip, Vol. 7, No.9 (2007), pp. 1146-1153.

(14) Suzuki, M., Yasukawa, T., Shiku, H. and Matsue, T, Negative dielectrophoretic patterning with different cell types, Biosensors and Bioelectronics, Vol. 24, No. 4 (2008), pp. 1043-1047.

(15) Albrecht, D. R., Underhill, G. H., Wassermann, B. T., Sah, R. L. and Bhatia, S. N., Probing the role of multicellular organization in three-dimentional microenvironments, Nature Methods, Vol. 3, No. 5 (2006), pp. 369-375.

(16) Albrecht, D. R., Underhill, G. H., Mendelson, A. and Bhatia, S. N., Multiphase electropatterning of cells and 
biomaterials, Lab on a Chip, Vol. 7, No.6 (2007), pp. 702-709.

(17) Farndale, R. W., Buttle, D. J. and Barrett, A. J., Improved quantitation and discrinination of sulphated glycosaminoglycans by use of dimethylmethylene blue, Biochimica et Biophysica Acta, Vol. 883, No.2 (1986), pp. $173-177$.

(18) Kim, Y. J., Sah, R. L., Doong, J. Y. and Grodzinsky, A.
J., Fluorometric assay of DNA in cattilage explants using Hoechst 33258, Analytical Biochemistry, Vol. 174, No. 1 (1988), pp. 168-176.

(19) Benya, P. D., Shaffer, J.D., Dedifferentiated chondrocytes reexpress the differentiated collagen phenotype when cultured in agarose gels, Cell, Vol. 30, No. 1 (1982), pp. 215-224. 